University of New Hampshire

University of New Hampshire Scholars' Repository

Languages, Literatures, and Cultures

Scholarship

Languages, Literatures, and Cultures

$1-1-2005$

\title{
Poetry and Mystical Heterodoxies: Leopoldo Panero
}

Manuel Asensi

Scott Weintraub

University of New Hampshire, scott.weintraub@unh.edu

Follow this and additional works at: https://scholars.unh.edu/lang_facpub

Part of the Spanish and Portuguese Language and Literature Commons

\section{Comments}

This is an un-refereed, pre-copyedited version of an article submitted for publication in Cien años de poesía-72

poemas españoles del siglo XX: estructuras poéticas y pautas críticas. Bern: Peter Lang, 2001. Discourse 27.1

(Winter 2005). Special issue on "Material Spirit." 84-97. The definitive publisher-authenticated version is available

from Wayne State University Press. http://www.jstor.org/stable/41389719

\section{Recommended Citation}

Weintraub, Scott. "Poetry and Mystical Heterodoxies: Leopoldo Panero". Translation of "Leopoldo Panero: Escrito a cada instante". By Manuel Asensi. In Cien años de poesía-72 poemas españoles del siglo XX: estructuras poéticas y pautas críticas. Bern: Peter Lang, 2001. Discourse 27.1 (Winter 2005). Special issue on "Material Spirit." 84-97.

This Article is brought to you for free and open access by the Languages, Literatures, and Cultures at University of New Hampshire Scholars' Repository. It has been accepted for inclusion in Languages, Literatures, and Cultures Scholarship by an authorized administrator of University of New Hampshire Scholars' Repository. For more information, please contact Scholarly.Communication@unh.edu. 


\title{
Poetic language as trans-symbolic: "Escrito a cada instante," by Leopoldo Panero"
}

\author{
Manuel Asensi
}

Escrito a cada instante

A Pedro Laín

1 Para inventar a Dios, nuestra palabra busca, dentro del pecho, su propia semejanza y no la encuentra, como las olas de la mar tranquila,

5 una tras otra, iguales, quieren la exactitud de lo infinito medir, al par que cantan...

Y Su nombre sin letras, escrito a cada instante por la espuma,

10 se borra a cada instante mecido por la música del agua; y un eco queda solo en las orillas.

¿Qué número infinito nos cuenta el corazón?

15 Cada latido, otra vez es más dulce, y otra y otra; otra vez ciegamente desde dentro va a pronunciar Su nombre.

Y otra vez se ensombrece el pensamiento,

20 y la voz no le encuentra.

Dentro del pecho está.

Tus hijos somos, aunque jamás sepamos decirte la palabra exacta y Tuya,

25 que repite en el alma el dulce y fijo girar de las estrellas.
Written at Each Instant

To Pedro Laín

To invent God, our word searches, within the heart, its own likeness and does not find it, like the waves of the tranquil sea, one after one, the same, seek the exactitud of the infinite to measure, as they sing in sequence... And God's name without letters, written at each instant by the foam, is erased at every instant rocked by the music of the water; and an echo remains alone on the shores.

What infinite number Does the heart tell us?

Every beat, is once again more sweet, and again and again; once again blindly from within is going to say God's name.

And once again thought shadows over, and the voice does not find it.

it is within the heart.

We are your children, although we never know how to tell you the word, precise and Yours, that repeats in the soul the sweet and fixed turning of the stars ${ }^{2}$

The poem by Leopoldo Panero reproduced above is of a mystical orientation and was inspired by Spanish poet Juan Ramón Jiménez. There is perhaps nothing less theological than the treatment of God in poetry. If, for theology, one's point of departure is certainty with respect to God, via what is called faith and belief, even outside of any experience of the divine, in poetry 
the direct experience of God carries the questioner beyond the opposition between certainty and uncertainty regarding divinity. This is affirmed by Plotinus, by San Juan de la Cruz (night of feeling and soul), by Hölderlin ("What is God? Unknown, rich / in particularities is, thus the aspect / that the heavens offer us of him"), by Rilke, and by Simon Weil, the latter with decisive clarity: "On God's part, creation is not an act of self-expansion, but of withdrawal and renunciation $(87)^{6 "}$ - creation is decreation. Poetic language, in the trans-symbolic sense that we are giving it here, develops the problematic of an infinitely absent and withdrawn God. Mystical experiences do not restore presence; on the contrary, they emphasize absence, in relation to which mystical experience itself is a strange and singular event. And for what reason does this take place in poetry? A simple reflection suffices as a response: The infinite withdrawal of God immediately poses the problem of God's name or nameability, and poetry - as in our century Blanchot, Derrida and Paul de Man, among others, have endlessly pointed out—does not cease to stress the distance between linguistic and phenomenal reality. In this impasse, poetic language and the infinite distance of God are brought into an encounter. However, since it cannot be said that God is a phenomenal reality, since God's distance is infinite, the problem of the distance between linguistic reality and what that reality names is therefore elevated to an equally infinite power, assuming the form of what would be a truly odd catachresis. Leopoldo Panero's poem, which stages what we have been discussing, could therefore not have begun any other way:

Para inventar a Dios, nuestra palabra [To invent God, our word]

Had the poem spoken of "naming," "designating," "signifying," etc., it would have erred by falling into the trap of simple theology. The attempt to name God would have simply taken 
God for granted, situated God in a "there" on the level of phenomenal reality, casting God as the figure of the father, the Father-God, a natural God, with white beard and triangle included. But the poem does not commit this error. Conscious of the infinite distance of God, it begins by affirming that God cannot be other than an invention, not because God does not exist and man must invent God, but rather because God's way of existing is absolutely unthinkable, and in this sense saying "God" is no more than the ingenous and misleading proximity that responds to the tricks and paradoxes of language paradoxically denounced by Lewis Carroll. The phrase "the car passed at full speed" is wholly similar to the phrase "time passed at full speed," yet the first is a phatic statement, while the second is contraphatic. Treating the two phrases as if they were the same type of statement is normal, but not epistemologically recommendable. To speak, says Blanchot, is to be sustained on a tomb, since the announcement and realization of our intimate relationship to death takes place in language, and poetry, compared to ordinary speech, does not cease to evidence our relationship to death. What poetry does do is give a second way of being to the thing: that of the zombie, the vampire. As we will see in this essay, mystic poetry, and more concretely the poetry of Leopoldo Panero, circumvents this way of officiating proper to language in poetry. If of the phenomenal thing, or body, one may say "Lazarus, come forth," it is because Lazarus was previously alive according to the mode of phenomenal existence. It is not possible to say Lazarus, come forth about God, since God was never alive according to that mode. So, then, what mode of being does poetic language assign to God? Panero tells us: "inventing God," to invent God, and therefore:

Para inventar a Dios, nuestra palabra 
In the trans-symbolic moment, which as we will later see is identified with rhythm, the expression "our word" does not join with the verbal syntagm that immediately follows it in the next few lines. Such a relationship is established in the linguistic-symbolic moment, when the other moment, the poetic one, is destroyed, or at least diminished. It turns out that from the point of view of the poetic, the expression "our word" stands alone in the midst of the silence that accompanies it, in the space and time of the first line. The entire poem reproduces the paradox of that which has sense in the absence not only of meaning but also of the very possibility of meaning. The graphic and rhythmic solitude of the expression "our word" in this first line suddenly represents the solitude of the word in the face of the thing that it names and the infinite solitude of the word in the face of the divine ${ }^{7}$. When, starting with the second line, the poem will restore semantic logic, it cannot say any more of "nuestra palabra" ("our word") than that it

busca, dentro del pecho, su propia semejanza y no la encuentra, searches, within the heart,

its own likeness and does not find it,

If in the first line the odd word was "inventar," the same strangeness occurs with the word "semejanza" (likeness), especially after the idea expressed there has circulated through the search that takes place within the heart. The poet Juan de Yepes searches for the Loved One who has disappeared in mountains, valleys, forests, rivers, wind, flowers, and dawn; he searches for the One in nature, continuing the allegory of spatial distance. Leopoldo Panero looks for the unknowable Loved One within the heart, in himself, since in his conception distance is not spatial, unless we think spatial distance as a mathematical sublime unresolved by Kantian reason and imagination. According to many Indian saints and yogis, there exists a spiritual heart, a 
center of energy that is situated to the right of the heart, in the chest. They assert that this spiritual heart is a nucleus of energy that connects to the heart of the universe. Consequently, one must seek God within oneself, and not in exterior nature. Line 21 suggests this: "Dentro del pecho está" ("God is within the heart"). Of course according to what these lines tell us, the search has a negative result, since it does not find its objective. Line three declares that "no la encuentra" ("[our word] does not find it"), and line 20 repeats it: "y ... no le encuentra" ("and . . .does not find God"). Man, after searching for God inside of himself and not finding what he is looking for, loses himself.

What is the most striking is the path that this search should follow in order to find its objective. I'm referring to this other odd word, "semejanza" (likeness). Our word seeks, according to the poem, its own likeness within the heart "and does not find it." Panero situates the process of the search for God in a linguistic medium; it is a matter of the word finding its own likeness, and thus, finding God. A surprising statement, since divine experience does not take place here through the channels of direct mystical contact, but rather through the linguistic medium, as if the task of the divine search—an invention, one must not forget—depended on language. On this point, we find ourselves close to Heidegger, who comments (via a poem by Stefan George, "The Word"), "No thing is where the word is lacking," and a bit later, "the being of any thing that is resides in the word." A bit earlier in the same essay, Heidegger had made the following statement: "even a God is a thing" (61-3). The link that Heidegger establishes between language and Being, between poetry and Being, is well-known. For this German philosopher, Hölderlin is the poet of the poets since the latter's work stages the essence of poetry, which consists of making possible parousia, the absolute presence of Being. In this reading of Panero's poem, we are close to this problematic of Heidegger's, but not in quite the 
same place. If "nuestra palabra" goes towards God in the search for "su propia semejanza," it is because in language, especially in its original poetic form, there remain traces of God (in language there are traces of the presence of God, says Augustine). Between the word and God, between God and the word there is a likeness, and therefore "nuestra palabra" cannot be just any word, but rather the poetic word. For no other reason does the word seek "su propia semejanza."

Again, however, we are close to Heidegger, but not in quite the same place, since if, according to this philosopher, Hölderlin's adventure finds what it was looking for (Being, of the thing or of God, who is also a thing), Panero's poem declares the failure of such an undertaking. The likeness is sought, but is not found. It is because God's distance is also-above all, we might add — infinite distance with respect to the word. This poem, like much of what is known as mystic poetry, is, among many other things, an allegory of the relation between word and thing. As Giorgio Agamben states, "poetry seems here to experience the originary event of the word itself as nothing" (74). On this point, Panero is closer to Blanchot and de Man than to Heidegger, since for the former two what poetry highlights is the fracture between linguistic and phenomenal realities. In other words, to put it in more rhetorical terms, that a word is seeking its likeness means that it is seeking a metaphor, and since, according to this poem, the word does not find its likeness, then the search for metaphor is a failure; what is found is not a metaphor but a metonymy. The poem deconstructs the possible analogy between the word and what it names, dismantles all traces of iconicity. However, Panero's poem will, if it were possible, take us a bit further than the conflicting theses put forth by Heidegger/Blanchot-de Man, since "Escrito a cada instante" does not limit itself to reproducing the eternal problem of the relation, whether positive or negative, between language and being, but tells us something more regarding the type of truth, or absence thereof, that poetic language may incarnate. 
In this sense, Panero's poem helps to formulate the idea in relation to poetic language that was mentioned at the beginning of this essay. Since the union with God does not take place, one might think that the poem pertains to the mystical register of the "noche del alma" ("night of the soul"). In that place where one should encounter God, in the heart, our word instead appears to find what cannot be found. But is God unencounterable because not present, or is God inaccessible by virtue of his abysmal nature? The lines that follow establish a correlation in which humankind's "we" and nature are together in the search process:

como las olas de la mar tranquila, una tras otra, iguales, quieren la exactitud de lo infinito medir, al par que cantan... like the waves of the tranquil sea, one after one, the same, seek the exactitud of the infinite to measure, as they sing in sequence...

Our word's process of searching is like the waves' effort to measure "la exactitud de lo infinito." An appeal to analogy and oxymoron. The word directs itself asymptotically and constantly towards God, just like the incessant swell of the sea ("otra vez [...], y otra y otra") pursues a paradox, because the concept of infinitude (the uncountable) can never be exact, and therefore cannot be measured. From this moment on, the (semantic) features proper to human activity that allow language to pass through that activity by way of poetry will exchange places with the natural process of the waves, trying to reproduce and measure the infinite macrocosmos. The human activity of poetry lends its humanity to the waves which, by virtue of this concession, acquire the peculiarity of having an intention, while at the same time these waves pass through the asymptotic repetition that is proper to the word in its direction toward God. The 
lines that follow confirm this through a condensation of the two spaces. But first it should be pointed out that the use of the verbs "medir" ("to measure") and "cantar" ("to sing") in the poem is not gratuitous, since both measure and song are names that refer to the metric-rhythmic component which is specific to poetic language. There is the mathematical measure and the measure (from the Latin mensura, mesura) proper to meter and rhyme. There is the human song, the song of the universe (". . la tierra que canta entre lo verde" [the earth that sings among the green], writes Vicente Aleixandre in his poem, “A ti, viva"), and the song taken or understood as poem. Measuring and singing provoke a self-reference in the poem; they allude to one of its fundamental dimensions: rhythm and meter. "Escrito a cada instante" employs the mold of the silva, with its combination of hendecasyllables and heptasyllables that are unrhymed save the occasional unmarked assonance. That the silva is also known as a free song does not mean that it does not take place within the limits of some fixed rhythmic and metric schemes_-it also shows a greater freedom than, for example, the sonnet (another type of poem employed abundantly by Leopoldo Panero).

The swell ("las olas [...] una tras otra") also represents a rhythmic motif. Although the qualifier "also" is unnecessary, since what is in question here is an essential representation: the etymological root of rhythm is, according to Emile Benveniste, rein, which literally means the regular flux of the waves. Consequently, the mention of the waves in the poem is full of semantic implications referring to rhyme. But from this moment on, the poem does not cease to indicate its rhythmic dimension, by means of numerous procedures, to the point that rhythm becomes the text's dominant semantic field: line nine speaks of the repetition of writing ("escrito a cada instante"); in lines 11 and 12 the motifs of music and the echo appear; lines 13 and 14 refer to "número” and "contar” (“¿Qué número infinito / nos cuenta el corazón?” [“What 
infinite number / "does the heart tell us?"]). Immediately after this, the reference to the beating of the heart appears ("cada latido"), directly following which the poem becomes iconically repetitive through morphological duplications accompanied by polysyndeton (otra vez [...], y otra y otra; / otra vez...] // Y otra vez [...] y [...]," lines 16-20), and in the final moments, namely in the penultimate line, comes the explicit mention of repetition ("que repite en el alma").

The question is: Why in the context of a reference to God, in which the musicalformalistic values of the poem should only have a mediating role, is the rhythmic component of poetic language suddenly mentioned? Why immediately after speaking about the likeness that the word seeks does the poem turn to the motif of rhythm? The presence of music in the poem could take us quite far. In fact, as already commented, line 11 names music again, this time directly: "Mecido por la música del agua" ("rocked by the music of the water"). But in the context of the concerns of this essay, one brief reflection is sufficient. First, it must be pointed out that the common conception of poetry's rhythmic-metric aspect as ornamental will be quite far from our concerns here. It has been said, for example, that rhythm interferes with logical and prosaic signification, interrupting it in order to create secondary or potential meanings (such was the argument of Russian Formalists Osip Brik and Iuri Tinianov with regard to rhyme, for example), that rhythm contains a pre-logical, libidinal, and pre-discursive meaning (Julia Kristeva), or that it possess a semantic value in itself (Meschonnic, or the aforementioned Agamben, for whom "the metrical-musical element shows above all the verse as a place of memory and a repetition" [79]), etc. None of these positions regarding rhythm could be drawn from Leopoldo Panero's poem, regardless of what the author's own intentions may have been in this sense. 
In principle, there is a historical-religious explanation for the link between rhythm and God: in most religious mysticisms, rhythm is one of the means by which one enters into mystical contact with God or divinity. In the Bhakti, one of the most important schools of religious practice in Hinduism, it is recommended that one practice kirtan and japa: to repeat, remember and sing the name of Krishna. In the Jewish Kabala, the meditator concentrates on each word of the daily prayer, repeating it without stopping to the point where the mind transforms the habitual meaning of the words in order to attain a higher state. This is precisely what Christian Hezekiahism proposed. In Sufism, the whirling dervish dance and the $z i k r$ are based on the continued rememoration of the name of Allah and on the spins that the dancer performs on his own body. Buddhist mantras, whether sung or repeated mentally, seek illumination. We could go on; this list of examples is only partial. Panero's constant references to rhythm as a form of searching for God is a trace that mystic, philosophical, and poetic textuality has imprinted in this poem, to which it has ceded. This would explain why the relation between poetry (in its different historical, textual forms) and God configures the basic constitution of poetic language from (for example) Democritus and Plato to Juan Ramón Jiménez passing through Jalaluddin Rumi and Rilke.

But the link between rhythm and God is a bit more sophisticated, as it were. For Mallarmé as well as Heidegger, Being (with a capital "B") is neither a substance nor form; it is rhythm. In his seminar on Heraclitus (from 1966), Heidegger develops this idea, emphasizing the fact that the Greek word rhusmos means something similar to "form," "configuration," or "disposition," which implies the determination of "form" as seal, trace, or inscription. In turn, Mallarmé speaks in very similar terms, of the "suprême moule" (mould, supreme matrix) as essence or truth of Being that can be observed in the visible signs of rhythm (345). Clearly, in 
such conceptions of the truth of Being as rhythm there is no essentialism or mimetism in operation, since for both the French poet as well as the German philosopher the trace or the supreme mould do not take place as things present. Derridean différance emerges from this interstice. To put it in an economical and simple way: the rhythmic truth of the poem is not expressive, nor mimetic, nor does it belong to the realm of the aesthetic without referent—rather, it is an emanation of Being understood as rhythm. In this regard, poetic language is not semiotic, it does not represent the recuperation of the maternal body, as argued by Kristeva, and, much earlier, although in different terms, by the futurists of the Russian avant-garde. To call poetic language semiotic, in Kristeva's terms, confuses the pre-rational with the post-rational, because poetic language is a post-symbolic language, to employ the Lacanian terminology used by Kristeva herself. The pre-rational, the pre-discursive lives for, is mouthed by, the symbolic, and in this state of anteriority language can never incarnate the rhythmic truth of the present/absent Being. In fact, what poetic language does is liberate itself as much as possible (which is never a liberation in the sense of a step beyond) from the symbolic, situating itself in a trans-symbolic state, demonstrating the non-symbolic fracture that persists in the symbolic. Poetic language is trans-semantic language.

That Panero's poem should speak of a failed search is not strange; since being as rhythm cannot find itself, the rhythm of the poem highlights an absence. And if this being is identified in this case with God, there is more reason for this discrepancy. As Juan Martín Velasco comments, all of the words belonging to the lexical field of mysticism derive from the Greek verb myo, which means the action of closing the mouth and the eyes due to the existence of secret, hidden, or mysterious realities (19-21). Thus Panero appeals to the invisible, the erased, to that which disappears: 
Y Su nombre sin letras,

escrito a cada instante por la espuma,

se borra a cada instante

mecido por la música del agua;

y un eco queda solo en las orillas.
And God's name without letters,

written at each instant by the foam,

is erased at every instant

rocked by the music of the water;

and an echo remains alone on the shores.

The poem, the rhythm ("cada instante $[. .$.$] cada instante [. .$.$] música [...] eco") arises from$ a paradox, that of the name without letters. A name without letters is a name without meaning, or with a meaning that does not belong to the logical plane of language and of the concept. The lack of logical meaning is proper to rhythm, as a de-semantization provoked by repetition and as aperture to other semantic possibilities, just like what happens in Jewish Kaballistic meditation. In this moment of the poem, the action of the human "we" and the action of nature are linked synchretically; the gesture of writing is carried out simultaneously by us and by the waves and the sea foam. The literal and the metaphorical fields have fused through an exchange of their semantic features. Such joint activity of searching for God takes place in the midst of no-sense. And it is here where we find one of the keys of poetic language, understood as an insurpassable negative relation between the symbolic and the trans-symbolic: to speak, as in this case, of a "nombre sin letras," written and erased at each instant, highlights the fact that repetition and rhythm create a fracture in the symbolic, freeing themselves from the symbolic (out of the symbolic) in order to provoke a cognitive expansion that could not take place simply within language. From language, from the word in its habitual function, it is not possible to access the referent in any way, much less God (Panero tells us). Rather than in the form of accessibility, 
this referent is understood in the poem through the intuition of a withdrawal (of God, in this case, but the retreat of the real in others) and of a presence unanticipated in the symbolic but which nonetheless must pass through that symbolic. Hence the recourse to mysticism. Therefore, the lines that follow can be considered tragic, since they sing, elegaically, the separation between the word and God, but also at the same time comic, since they possess the pleasure of uncertainty (or unanticipated certainty) given by rhythm. The repetition is infinite and sublime; the asymptote of language arisen from the heart has no end:

¿Qué número infinito nos cuenta el corazón?
What infinite number

Does the heart tell us?

As such a repetition, as the mode of the poem's installation in the trans-symbolic plane which we've been speaking about, rhythm is sweet, because of the cognitive expansion, because of what it opens in the negative wall within and outside of language. However, insofar as the poem remains in the symbolic, in the plane of logic, failure and separation do not cease to be produced. Paneros' text combines and makes triumph and defeat co-exist in the same context through the use of words and expressions whose connotations are both positive and negative. It should be noted, nevertheless, that the placement of the words which join and those which imply distance is strategic. In what sense? In the sense that the unifying turns correspond to the transsymbolic plane, as for example in the lines: 
Cada latido,

otra vez es más dulce, y otra y otra;
Every beat,

is once again more sweet, and again and

[again

And, however, corresponding to the symbolic plane are words and expressions that indicate failure and distance:

otra vez ciegamente desde dentro

va a pronunciar $\mathrm{Su}$ nombre.

Y otra vez se ensombrece el pensamiento,

y la voz no le encuentra. once again blindly from within

is going to say God's name.

And once again thought shadows over, and the voice does not find it.

This distribution, carried out from two planes which exclude each other but nevertheless need each other (symbolic/trans-symbolic) in the mode of an insurpassable negative dialectic, is reproduced in the final lines of the poem:

Tus hijos somos,

aunque jamás sepamos

decirte la palabra exacta y Tuya,

que repite en el alma el dulce y fijo

girar de las estrellas.
We are your children, although we never know how to tell you the word, precise and Yours, that repeats in the soul the sweet and fixed turning of the stars

Enunciated here is the consciousness of a truth understood as, to cite the words of Paul de Man, "the recognition of the systematic character of a certain type of error" (17) which consists 
in thinking that the word arrives at the terminus of its object. Consequently, the poem denies that we know how to say the exact word. But at the same time there is a consciousness that repetition itself, Being as rhythm (as we previously discussed), takes us directly to the transsymbolic plane where the cognitive expansion attracts the unsayable and the unthinkable, and for this reason the repeated turning of the stars in the soul is, once again, sweet. Panero's poem does not fall into the opposition Voice/writing, because there are as many references to the one as the other, as many references to an external language as they are to an internal one. If, on the one hand, the waves sing, and the heart's beats pronounce "God's name" with a voice that "does not find God," on the other hand the foam writes, and repetition presupposes a materiality present in all parts of the text, while language also takes place in the interior of the heart and thought, as well as in the exteriority of sound. The essentially repetitive character of the trans-symbolic plane necessarily deconstructs the opposition Voice (Speech) / writing because both are mutually supportive as symbolic language from the start, and what the poem does is extricate itself from both to achieve its natural trans-symbolic state. Hence this poem's hypogram (Riffaterre, de Man) is constituted through the expression in line 9 that gives the poem its title, as well as naming the book of which it is part. It is "escrito a cada instante." In this expression, the idea of the search for God (or the thing, in general) in a permanent asymptote of the symbolic plane converges with a rhythm that strips the expression itself of its semantic-logical content in order to situate itself in the trans-symbolic plane. One writes, and writing is a search which is constant and destined to failure; what the foam writes, the water erases; what is about to be pronounced ends up in aphasia ("se ensombrece el pensamiento, / y la voz no le encuentra") ("thought grows dark, / and the voice does not find it"). But the fact that one writes rhythmically and repeatedly, the recurrent and ordered alternation of the waves that come and go one after another, the music, 
the turning of the stars, opens up a consciousness of the unsayable, since "dentro del pecho está" ("He/it is inside the heart") — even if this "is" is not that of mere presence, but rather of the constancy of divine decreation. Such a hypogram can only be buried, subjected to the sweet turning of repetition. Rumi says: "Hasta caer en un profundo sueño / te acunaron las esferas que giran," ("Until falling into a deep sleep / the turning spheres rocked you"), but also "No estamos delante ni detrás, / no estamos ni arriba ni abajo. ..." ("We are not in front nor behind, / we are neither above nor below. ...”).

\section{Notes}

${ }^{1}$ This essay was originally published in Cien años de poesía-72 poemas españoles del siglo XX: estructuras poéticas y pautas críticas (Bern: Peter Lang, 2001). It is translated and reprinted by permission of Peter Lang.

${ }^{2}$ Spanish poet Leopoldo Panero (1909-1962), member of the so-called "Generation of '36," was an art critic, member of the Instituto de Cultura Hispánica during the 1950's, intimate friend of Luis Rosales and José María Valverde, and father of an anxiety of influences of a virtual saga of Panero poets. In 1940 he published a selection of poems in the journal Escorial, as well as the long poem "La estancia vacía" (1944). The book which bears the same title as the poem discussed here, Escrito a cada instante, was published nine years later, in 1949, and subsequently received the Fastenhrat Prize from the Royal Academy of Spain. In 1950 Panero published Canto personal: Carta perdida a Pablo Neruda, written in response to Neruda's Canto general. His Poesía: 1932-1960 appeared in 1960, with a preface by Dámaso Alonso, published by Ediciones de Cultura Hispánica. Panero's son, Juan Luis Panero, edited the two-volume 
Obras completas in 1973 (one volume of poetry, the other prose) as well as Antología, both published by Plaza y Janés Editorial. In 1994, Andrés Trapiello edited an anthology of Panero's work entitled Por donde van las águilas, published by Editorial Comares de Granada.

${ }^{3}$ In reflecting on the relation, between language and mysticism, I am in part drawing on Massimo Baldini’s Il linguaggio dei mistici as well as Lawrence J. Hatab’s essay, "Mysticism and Language."

${ }^{4}$ To be understood as language in a determined historical moment functioning poetically. ${ }^{5}$ In this Derridean sense, my affirmation distances itself-for reasons that will become clearfrom Jean Cohen's otherwise similar argument in El lenguaje de la poesía (teoría de la poeticidad) (originally published as Structure du langage poétique; Paris: Flammarion, 1966), that "poetry appears as pure negativity, deconstruction of the very structure of language" (69). ${ }^{6}$ Translator's note: the word "restraint" in the English translation of Weil's sentence has been modified to "withdrawal," to reflect the Spanish translation used by Asensi (A la espera de Dios, Valladolid: Trotta, 1996, p. 91), in which the word is rendered as "retirada."

${ }^{7}$ This graphic-rhythmic solitude, a common characteristic in poetry, can be found disseminated throughout the text in the formation of illogical links, such as, for example, the phrase "cada latido" ("each beat") (line 13 or 12), although logically and syntactically is accompanied by the attribute "es más dulce" ("is sweeter") (16), is nevertheless metrically linked to the previous line, “... nos cuenta el corazón?” (“. . does the heart tell us?”) (12)—or, for example, in the graphicrhythmic solitude of the "jamás sepamos" ("we may never know") of line 23, etc.

\section{Works Cited}


Agamben, Giorgio. Language and Death: The Place of Negativity. Trans. Karen E. Pinkus with Michael Hardt. Minneapolis: U of Minnesota P, 1991

Aleixandre, Vicente. Antología total, Barcelona, Seix Barral, 1977

Baldini, Massimo. Il linguaggio dei mistici. Brescia: Queriniana, 1999, $2^{\text {nd }}$ Ed.

Benveniste, Emile. “The Notion of 'Rhythm' in its Linguistic Expression.” In Problems in General Linguistics. Trans. Mary Elizabeth Meek. Coral Gables, Florida: U of Miami P: 281-289.

Cohen, Jean. El lenguaje de la poesía (teoría de la poeticidad). Madrid: Gredos, 1982

de Man, Paul. “Semiology and Rhetoric.” In Allegories of Reading: Figural Language in Rousseau, Nietzsche, Rilke, and Proust. New Haven: Yale UP, 1979.

Hatab, Lawrence J. “Mysticism and Language.” International Philosophical Quarterly 22 (1982): 51-64.

Heidegger, Martin. “The Nature of Language.” In On the Way to Language. San Francisco: Harper, 1971.

Mallarmé, Stéphane. “Solennité.” In Oeuvres Complètes. Paris: Gallimard, 1945.

Rumi, Yalal al-Din. En brazos del amado (antología de poemas místicos). Madrid: Edaf, 1998. Velasco, Juan Martín. El fenómeno místico. Valladolid: Trotta, 1999.

Weil, Simone. Waiting on God. Trans. Emma Crawfurd. London: Routledge, 1952. 